\title{
Local Management of a Global Commons? The Case of Climate Standard Development in the Swedish Food Sector
}

\author{
Karl Johan Bonnedahl ${ }^{1}$ \\ ${ }^{1}$ Umea School of Business and Economics, Umea, Sweden \\ Correspondence: Karl Johan Bonnedahl, Umea School of Business and Economics, Umea University, S-90187 \\ Umea, Sweden. Tel: 46-907-866-524. E-mail: Karl.Bonnedahl@usbe.umu.se
}

Received: July 11, 2014

Accepted: September 29, $2014 \quad$ Online Published: October 22, 2014

doi:10.5539/ijbm.v9n11p31

URL: http://dx.doi.org/10.5539/ijbm.v9n11p31

\begin{abstract}
Focusing on climate change, this article discusses possibilities of a local approach to complex global environmental problems. Due to failures of markets and international politics as strategies to govern the atmosphere, an alternative approach could be voluntary initiatives in which the complexity of the global common-pool resource (CPR) is reduced. Assessing such an approach through a case study of food standard development in Sweden, the outcome is two-sided. By means of scientific explanations and stakeholder dialogue, standards were produced, but attentiveness to CPR management diminished as focus turned towards producer interests and efficiency increasing measures. Although the climate issue was promoted, the outcome was far from the needed change and illustrates difficulties to deviate from prevailing priorities. In order to balance local interests and power with global and intertemporal values, and reach absolute emission cuts, change in norms and governance on every level would be needed.
\end{abstract}

Keywords: climate, commons, CPR, design principles, food production, governance, labels, standards, stakeholders

\section{Introduction}

The human pressure on the environment is so great that is claimed that we have left the relatively stable Holocene behind and entered Anthropocene (Crutzen, 2002; Steffen, Grinewald, Crutzen, \& McNeill, 2011). Not only have our actions and the scale of our societies become the main drivers of environmental change (cf. McKibben, 1989); as Rockström et al. (2009, p. 2) argue, we are destabilising ecosystems and run the risk of triggering "abrupt or irreversible environmental changes that would be deleterious or even catastrophic for human well-being." More than so, Jeffrey Sachs (2011) says that we are beyond the tipping point, and Lester Brown (2011) urges us to stop talking about sustainable development and instead talk about saving the civilization.

In this multi-dimensional task, some challenges are greater than others. Among the more difficult ones is the need to handle large scale, multiple source and effect environmental problems such as biodiversity loss and climate change (Ostrom, Burger, Field, Norgaard, \& Policansky, 1999; Soroos, 1998). Focusing the latter, scientific consensus on climate change, including the magnitude of the problem and its anthropogenic causes, has been established and spread to other sectors of society (IPCC, 2007; World Bank, 2012). This includes industry, where actors are making or communicating attempts to reduce their climate impact (Kolk \& Pinkse, 2004; Okereke, 2007). Improvements, however, are typically only relative to measures of economic activity (Frye-Levine, 2012) and, on the aggregate, emissions of greenhouse gases (GHG) continue to increase (NOAA, 2013; PBL \& IES, 2011).

The basic reasons for this development have been well presented in the IPAT model (Erlich \& Holdren, 1971; Mitchell, 2012). Sharp rises in population (P) as well as in consumption per capita (affluence; A) outweigh gains from improvements in the forms of production, organisation and distribution (technology; T). The result is continuous growth in environmental impact (I); not least through GHG emissions. Changes in consumer preferences and institutional settings have proven inadequate to trigger substantial business sector responses to the climate challenge. The demand for "green" products and services is generally marginal, competition makes individual firms reluctant to take radical steps that are presumably financially risky, and the political sphere, 
independent of level, has not reacted amply by creating regulation, cost structures or incentives that would favour transformation (e.g., Trucost, 2013; World Bank, 2012).

For the benefit of improving economic efficiency and meeting individual aspirations to consume, our capacity and preparedness to manage collective environmental problems may even have been reduced, and our societies less resilient (Duit, Galaz, Eckerberg, \& Ebbesson, 2010), as a result of economic liberalisation and globalisation during the last quarter of a century. According to the associated economic discourse, business actors are expected to seek growth and maximize profits (cf. Armour, 1997; Oels, 2005), which is consistent with the assumed rationality of the herdsmen on the commons for which Garrett Hardin (1968) famously described a tragedy. The basic reason for this environmental and social tragedy is that a user of a common-pool resource (CPR) can draw the benefit of his use while the costs (environmental degradation) of the same activity are borne by all. As the atmosphere has such characteristics, "a pasture open to all" (Hardin, 1968, p. 1244), climate change presents a collective problem resembling the tragedy of the commons.

Being so, today's reliance on voluntary initiatives by market actors, to demonstrate and implement low-carbon routes of action in flexible and cost-efficient ways, certainly presents questions. Research results are ambiguous as to what extent environmental problems, largely caused by the use of individual reason and market exchange, will be solved by voluntary means (Alberini \& Segerson, 2002; Ostrom, 2008), and climate change is, in the words of Stern $(2006$, p. 1), "the greatest example of market failure we have ever seen". Learning from Hardin's seminal article (1968), we would depend on property rights or coercion created by centralized political measures to combat climate change. However, institutional structures at the atmospheric level are weak (Gardiner 2011; Soroos, 1998), and looking at emission pathways, attempts by the parties to the United Nations Framework Convention on Climate Change to find relevant post-Kyoto solutions has failed (UNEP, 2011; World Bank, 2012).

This may lead us back to earlier experiences of self-governing institutions as stewards of environmental resources. Although such institutions, different from pure markets and centralized political measures, have typically been locally evolved and buffered from outside forces (Burger \& Gochfeld, 1998; Stern, 2011), research has presented guardedly optimistic views on the possibility to transfer learning to large-scale environmental problems (Dietz, Ostrom, \& Stern, 2003; Ostrom et al., 1999). Dietz et al. (2003) propose that attempts to manage global environmental resources could succeed if they avoid reliance on imposed markets or centralized control, employ a variety of decision rules, and involve actors in broad dialogue.

These propositions are aimed at adapting governance strategies for global resource commons to the complexity of the problems and their context, an approach which has been developed further by, among others, Stern (2011, p. 223) due to the "governance challenges that do not emerge prominently in the literature on local commons." (cf. Morrow \& Hull, 1996). A different strategy would be based on attempts to handle such challenges through a reduction of complexities. The rationale would be to strengthen or recreate features that made small-scale institutions successful (Stern 2011, p. 215) and facilitate more rapid responses. As one example, it could be feasible to approach the climate system from a local or national setting (cf. Bunzl, 2009), thereby meeting prevalent institutions and other factors, such as language and common understandings, that influence the scope for successful design and implementation of common rules (Stern, 2011). This could also conform to the findings that communication and repeated interaction facilitate the solving of social dilemmas (Driscoll, 1996; Gardiner, 2002; Ostrom, 2000). Such processes may be further eased if the variety of stakeholders and activities involved were reduced (cf. Gulbrandsen, 2005; Stern, 2011); for instance if industries were targeted individually. Thus, attempts to reduce complexities may lower difficulties and costs that users of CPRs face when they negotiate, monitor, and enforce rules for the commons (cf. Ostrom et al., 1999, p. 279-280).

Subsequently, acknowledging the limitations of a reductionist approach to common environmental problems, this article investigates complexity-reducing voluntary initiatives as a form of management of the climate commons. A longitudinal case-study approach is adopted, with the development of a climate standard, and related labels, for the Swedish food sector as case. This project was run by some of the major domestic industry organisations, but a variety of other actors, including government and civil society organisations (CSOs), participated in different ways. The purpose of the article is to assess the project's potential and limitations in terms of change towards low-emitting food sector practices and, hence, (local) management of the climate commons.

This assessment has three components. The structure of the initiative under study, as a governance system, is examined in relation to design principles and requirements for sustainable systems as presented by Dietz et al. 
(2003) and Ostrom $(2005,2008)$. Further, the role of stakeholder interaction in the development of the emerging system is examined, and, in order to indicate the impact on practice, the content of the initiative is discussed on the basis of the resulting standard and labels.

\section{The Tragedy of the Climate Commons}

\subsection{Climate Change and CPR Management}

Although not mentioned explicitly in 1968, climate change is an example of the tragedy of the commons as it was treated by Garret Hardin. He discussed how we put "dangerous fumes into the air" (p. 1245) with the same calculation as when we use a commons to let our cattle graze (cf. Burger \& Gochfeld, 1998; Paavola, 2008; Soroos, 1998). Presuming we are all rational beings, seeking to maximize our gain, Hardin analyses our behaviour as being directed by a utility function with two components: "Since the herdsman receives all the proceeds from the sale of the additional animal, the positive utility is nearly +1 ." However, as "effects of overgrazing are shared by all the herdsmen, the negative utility for any particular decision-making herdsman is only a fraction of -1." As long as we "behave only as independent, rational, free-enterprisers" (Hardin, 1968, p. 1245) the conclusion is clear: We are locked into a system that compels us to increase activities that drive degradation of the CPR.

A CPR is characterised by difficulties to define and exclude users (Ostrom, 2008), and the tragedy of the commons situation is one where users are overexploiting a CPR and impose externalities upon each other (Hsu, 2005). This is particularly a problem for open-access type of resources such as the atmosphere (Burger \& Gochfeld, 1998; Ostrom, 2008). We do not even need to meet strict criteria as maximizers for the problem to arise. Preferences in line with herdsmen in the example, together with inadequate institutions, or enough many people, firms and governments that overharvest (Bunzl, 2009), will create the unfavourable situation. Here, Hardin is pointing at a key element behind environmental degradation, differences between private and social costs; and as he puts it in a later comment (Hardin, 1998), our ego-centred impulses impose costs on the group under conditions of scarcity.

As the general pressure on ecosystems has become significantly higher, today's decision making context is even less favourable than when Hardin presented the problem. The global population has doubled, and on the basis of a massive use of fossil fuels and other elements, systems and species in nature, the scale of our activities has expanded even more (Hardin, 1998; Crutzen, 2002; Steffen et al., 2011). As one consequence, climate change has emerged as a mega-threat to humanity and other species. From the point when Keeling's Mauna Loa observations started $(1958,315 \mathrm{ppm})$, annual increases of carbon dioxide have tended to grow, and the atmospheric level (394 ppm as annual mean in 2012; NOAA, 2013) is $40 \%$ above the pre-industrial period's range of variability, one of the circumstances that enabled life on Earth as we know it (Rockström et al., 2009; Steffen et al., 2011).

Moreover, our institutional arrangements have moved further towards supporting Hardin's "independent, rational, free-enterprisers". In 1968, Hardin regarded the institution of private property, the legal basis for these enterprisers" exchange and accumulation, as unjust, but still as an alternative to the commons as "Injustice is preferable to total ruin" (p. 1247). The effectiveness of this institution was already questionable: the air and waters, which cannot be fenced, must, Hardin argued, be protected by other means as the human population exceeds the capacity of nature's recycling processes. Nevertheless, attempts have been made to expand property rights to deal with climate change (e.g. as emission allowances within the European Union's Emissions Trading System), but judging from the increase in emissions, this and other central economic institutions (including free market and trade) have proven ineffective in terms of handling climate change (cf. Paavola, 2008; Stern, 2006). One reason may actually lie in the paradoxical solution, which establishes the link between right to property and right to emit.

The alternative would be a regime that connected resource users (emitters) with consequences of the use. In this vein, Hardin (1968) argued for social arrangements that produce responsibility. To not only become "attempts to get something for nothing", such arrangements must create coercion of some sort, but coercion that would be "mutually agreed upon by the majority of the people affected" (Hardin, 1968, p. 1247). Hence, Hardin was not far from recognizing self-governing (local) institutions (cf. Dietz et al., 2003; Ostrom et al., 1999). Such institutions, often found in subsistence societies, have however come under pressure. This is not least due to the population pressure that Hardin was discussing, but also due to the expansion of commerce and the creation of institutions to enable and regulate trade, transportation and competition; institutions that "shape environmental impact, even if they are not designed with that intent." (Dietz et al., 2003, p. 1908). 
Subsequently, humanity's governance challenge, to establish institutions that manage climate change, is difficult (Stern, 2011). The reasons include the problem's scope and scale, which may impede interaction and communication (Ostrom, 2000) and exacerbate the difficulty of organizing, agreeing on rules, and enforcing rules (Ostrom et al., 1999). More fundamentally, however, the open access - that anyone can contribute to the atmosphere's degradation - and the time dimension of climate change make our situation worse than on Hardin's commons (and in a conventional prisoner's dilemma). Adding the intergenerational problem, benefits of burning fossil fuels, keeping cattle, logging, etcetera, are reaped today while effects of emissions accumulate and become worse for future generations (Burger \& Gochfeld, 1998; Gardiner, 2002, 2011). Further, in contrast to the situation among the herdsmen, future generations can not present a claim or have influence over what we do today. In stakeholder terminology, this means that power takes precedence over legitimacy (cf. Mitchell, Agle, \& Wood, 1997). From this analysis it is not only "reasonable to expect that the commons will be deeply harmed by the present generation"; as each generation faces a decision situation with the same structure, "pollution will continue as long as the earth can bear it." (Gardiner, 2002, p. 404).

Although the first two generations to succeed the one of Hardin hasn't proven Gardiner wrong, efforts to reach sustainable CPR governance could learn from cases where achievements has been made. In this respect, Ostrom (2008) and Dietz et al. (2003) present five basic requirements for the design of sustainable systems. First, we need accurate information about the relevant resource system and human-environment interaction. Ideally, information should meet scientific standards as well as the need of users (Dietz et al., 2003). When we deal with large-scale resources and problems such as the climate from the local level, a situation that is more difficult than on Hardin's commons, local interests need to be balanced against global and more abstract interests and values (Dietz et al., 2003).

Second, any ambition to substantially change resourse use confronts prevailing ideas, behaviours and power structures (Steffen et al., 2011). Hence, governance systems should be designed so that conflicts can be discovered and solved (Dietz et al., 2003; Ostrom, 2008). As a third requirement, rule compliance is related to whether or not users of the commons consider rules "legitimate, fair, enforced, and likely to achieve intended purposes." (Ostrom, 2008, p. 18). Users should also take some responsibility for monitoring, while those who impose enforcement mechanisms must be seen as effective and legitimate (Dietz et al., 2003; Ostrom, 2008). Further, there are indications that the combination of community-based institutions and markets (e.g. regional tradable resource use permits) would work better than any of the two approaches alone (Dietz et al., 2003).

Fourth, successful governance must include infrastructure to enable and restrict operations within the commons and link resources, users and larger regimes (Ostrom, 2008). This includes physical, technological and institutional infrastructure (Dietz et al., 2003). Fifth, institutional arrangements must enable change as knowledge develops or as social or biophysical circumstances change (Dietz et al., 2003).

\subsection{Voluntary Governance Systems and Delimitation of the Commons}

Following failures of private markets and incapacity of international regulation, interest has been shown for voluntary systems for coercion (Ahn, Bush, Mol, \& Kroeze, 2011; Alberini \& Segerson, 2002; Ostrom, 2008). However, users of a CPR, or, in practice, influential stakeholders to such voluntary initiatives, must not only highly value the sustainability of the CPR; they must also overcome the "dilemmas they face in bearing the cost of designing, testing, and modifying governance systems" (Ostrom et al., 1999, p. 279). As "perceived costs are higher when the resource is large and complex, users lack a common understanding of resource dynamics, and users have substantially diverse interests" (Ostrom et al., 1999, p. 280; cf. Gulbrandsen, 2005), it may be fruitful to reduce some of the complexity when we deal with global CPRs. Complex large-scale problems would then be approached from a number of delimited initiatives, each of them targeting aspects of the wider problem.

A more workable format for interaction among users could meet the need for rapid action, as our time and space for manoeuvring is shrinking (Brown, 2011; UNEP, 2011). Hereby, it also addresses the moral convenience that complexity may imply, providing each generation "with the cover under which it can seem to be taking the issue seriously" (Gardiner, 2011, p. 48). Further, it would correspond to findings concerning functioning governance systems, often limited in geographic scale and number of appropriators, and homogeneous in terms of cultural and institutional context (Burger \& Gochfeld, 1998; Ostrom, 2005; Stern, 2011). In such examples, degradation has also been a direct effect of intentional action (e.g. fishing) while appropriators have had common interests (e.g. keeping the stock), and the properties of the resource system have made learning from experience possible.

Climate is different in all of these dimensions, but voluntary complexity-reducing initiatives would not contradict more comprehensive efforts to combat climate change. If successful, they could rather contribute to the acceptance of stricter approaches such as carbon taxes (Bonnedahl \& Eriksson, 2011; de Boer, 2003) and be 
part of broader systems of polycentric governance (Ahn et al., 2011; Ostrom, 2000, 2005). Such systems are needed not least to deal with inter- and intragenerational issues. While consequences and rights over time pose problems with any approach to governance (Gardiner, 2002), the corresponding problems over space are enhanced compared to a potentially successful comprehensive approach to a global CPR (cf. Hovik, Sandström, \& Zachrisson, 2010).

As this article suggests, an approach to governance in which reduction of complexity is sought for could depart from narrow definitions of the problem, its causes, its relevant place, or consist of combinations in these dimensions. As an example of the first type, initiatives could take departure in aspects of a wider environmental problem; such as drought or floods as consequences of climate change, leading to focused efforts to minimize or adapt to these issues. Likewise, certain direct causes to the problem could be focused, such as individual greenhouse gases, and underlying or behavioural sources to the problem could also be addressed in a delimited fashion, for instance via activities or practices (leading to, e.g., GHG emissions and finally drought, floods, etcetera). Lastly, governance systems could be created for certain geographical areas.

Rules and certification schemes for sustainable forest management can illustrate a combined approach. Such schemes, set up by various non-state actors, typically track products from approved forestry practices through the supply chain to the stage of product labelling (Gulbrandsen, 2005). Most well-known among these, the Forest Stewardship Council has a high-complexity approach to the problem, as it apart from a variety of environmental claims (e.g. biological diversity, water resources and ecological functions) addresses issues such as the rights of workers and indigenous peoples (Bloomfield, 2012; FSC, 1996). The economic and physical activities by humans are, at least implicitly, addressed as direct causes to the problems while demand and socio demographic change can be seen as underlying causes (cf. MA, 2005, p. vii). This complexity is reduced through the focus on a specified human practice. The system is international but involves a variety of stakeholders on various levels and aims to manage local resources and ecosystems with global consequences, not least in terms of biodiversity and climate.

Table 1 summarizes these suggested bases for determination and reduction, but certainly not elimination (cf. Beland Lindahl, Baker, \& Waldenström, 2013), of complexity. Examples of lower and higher complexity are given with departure taken in the climate CPR.

Table 1. Different bases for the reduction of complexity, with examples

\begin{tabular}{lllll}
\hline $\begin{array}{l}\text { Approach to } \\
\text { complexity }\end{array}$ & lower & Degree of complexity & higher \\
\hline Problem & $\begin{array}{l}\text { Drought related challenges for food } \\
\text { production }\end{array}$ & $\begin{array}{l}\text { Challenges for } \\
\text { systems } \\
\text { structures }\end{array}$ & $\begin{array}{l}\text { production } \\
\text { economic }\end{array}$ & $\begin{array}{l}\text { Pressure on ecosystems, species } \\
\text { and societies }\end{array}$ \\
\hline Direct cause & $\mathrm{CO}_{2}$-emissions & GHG-emissions & $\begin{array}{l}\text { Direct emissions, change in land } \\
\text { use and other factors }\end{array}$ \\
\hline Underlying cause & Fuel/energy use in transportation & Logistics, physical planning & Organization on \\
& & & markets, \\
\hline Place & Local & National & Global \\
\hline
\end{tabular}

If we follow Dietz et al. (2003) and Ostrom (1990, 2005, 2008), any attempt to govern large-scale CPRs through a complexity-reducing approach should also relate to the design principles found to meet requirements of adaptive governance (presented above). The first (1) of six basic principles, to clearly define boundaries of resources and user groups, actually need some kind of reductionist method to become applicable for global commons (cf. Stern, 2011, p. 219). As a relevant complexity-reducing approach would facilitate the identification of ecological conditions and users, it could also enable (2) the making of rules that allocate benefits from harvesting in proportion to costs of operating the system (Ostrom, 2005), and (3) a structured and informed dialogue involving affected parties (Dietz et al., 2003; Ostrom, 1990, 2008).

Stern (2011) points at the greater difficulty in implementing the remaining three basic principles for global commons: (4) monitoring, and accountability mechanisms for monitors, (5) graduated sanctions for violations, and (6) local low-cost arenas for conflict resolution. This could argue for complexity-reducing initiatives, but 
difficulties to handle causes and effects across local governance-building arenas has to be recognized, and local initiatives would need to conform to the additional two principles, dealing with relationships between levels and domains of authority: (7) Users should have the rights to devise their own institutions, and (8) adaptive governance should be nested in layers, from local to global (Ostrom, 1990, 2005).

\section{Method}

Drawing on Pettigrew's (1990, p. 268) ideas on "theoretically sound and practically useful research on change", a longitudinal single case study approach was chosen. It should gain understanding of the development and outcome of an attempt to reach voluntary reductions of the human impact on the climate (cf. Siggelkow, 2007), and to be selected, a case should qualify as complexity-reducing in at least two of the dimensions in table 1 . Further, it should not be confined to minor activities or marginal actors in society. Such initiatives may certainly display profound and progressive responses to climate change, but an initiative with broader involvement, but still relatively high environmental ambitions, could provide a more relevant indication of major obstacles and success factors. Apart from enabling such learning, the chosen Swedish case, "Climate Certification for Food" (CCF), provides an opportunity to study change through "the contexts, content, and process of change together with their interconnections through time" (Pettigrew, 1990, p. 268) in a sector with considerable emissions and links to local habits as well as to international trade (FAO, 2006; Sonesson, Davis, \& Ziegler,2010).

While regulation in the food sector, particularly agriculture, has remained strong in Europe, recent decades have seen efforts to develop market mechanisms, voluntary agreements, competition and trade (cf. Feindt, 2010; Jordan, Wurzel, \& Zito, 2013). Hence, apart from allowing a study of complexity-reduction and the use of the basic design principles (Dietz et al., 2003; Ostrom, 1990, 2005), the setting may display an openness for variety (principle 7 above) and a relatively clear structure for regulation (nesting; 8 above). Regarding the latter, as Sweden is part of the European Union (EU) and its Common Agricultural Policy (CAP), Swedish food market actors mainly operate under the same regime as actors elsewhere in the Union. Other policy areas may also influence the direction of CCF, as a voluntary change initiative, as well as the possibilities to transfer learning to other institutional settings. Main areas of this kind are listed in table 2.

Table 2. Policy areas related to the CCF project

\begin{tabular}{ll}
\hline Policy area & Description \\
\hline Product information & $\begin{array}{l}\text { The National Food Administration monitors labelling together with quality and safety } \\
\text { issues. Common EU rules affect claims about, e.g., product origin and organic production. } \\
\text { The scope for voluntary claims about climate impact is large. }\end{array}$ \\
\hline Competition & $\begin{array}{l}\text { Harmonized rules regarding intra-EU matters (larger firms or trade effects). Co-operation } \\
\text { must avoid traits of collusion and protectionism. }\end{array}$ \\
\hline Environment & $\begin{array}{l}\text { CAP provides the general framework for primary production in EU member states. The } \\
\text { Swedish Board of Agriculture is the main national authority, with sustainable } \\
\text { development as official aim. A national target for organic production is an example of } \\
\text { environmental focus. The Federation of Swedish Farmers has an important role in national } \\
\text { policy. } \\
\text { The Swedish parliament has declared the aim to cut national emissions with } 40 \% \text { by } 2020, \\
\text { unspecified in terms of sectors. Sweden has a CO }{ }_{2} \text {-tax, but most is deducted for farmers to } \\
\text { not reduce international competitiveness. The voluntary climate initiative is in line with } \\
\text { policy. }\end{array}$ \\
\hline $\begin{array}{l}\text { Swedish regulation does not allow full industrialization of animal production but includes } \\
\text { issues of animal welfare (e.g. sizes and types of boxes and cages), claimed to imply cost } \\
\text { disadvantages relative to foreign animal production. These rules would support the broad } \\
\text { sustainability and ethical ambitions of CCF but could conflict with ambitions to improve } \\
\text { efficiency. }\end{array}$ \\
\hline Animal husbandry
\end{tabular}

The key actors behind CCF were two standard developing organisations on the Swedish food market: KRAV within organic food, including imports, and The Swedish Seal of Quality (SSQ) focusing conventional Swedish produce. Between 2007 and 2012, with a primarily domestic scope, these organisations lead a comprehensive effort to develop standards and labels for food production with low GHG impact. Many actors were involved in 
various ways, in what can be described as a multi-stakeholder (Roloff, 2008) or issue (Frooman, 2010) network, initiated to address an issue that concerns actors from different societal spheres.

From the start, CCF had a high complexity approach as regards problem identification (dimension one, table 1). While climate change was focused, other environmental and social goals were already part of the basic standards of the two key organisations (e.g. animal welfare and GMO free products). Further, human activities in a broad sense were approached as causes: directly, not least land use, $\mathrm{CO}_{2}$ from fossil fuels, and methane from ruminant livestock and manure, and, indirectly, through international transportation, meat production, etcetera (KRAV, 2007). The focus on food production, chiefly primary production, in a domestic setting was what reduced complexity.

In order to gain an understanding of the case and its context, and as a key source of empirical material, document data was gathered throughout 2008-2012. The opportunity to follow most of the process in real time minimized time related methodological challenges (cf. Halinen \& Törnroos, 2005; Pettigrew, 1990). Good access was enabled due to CCFs open approach, including the provision of on-line documentation (e.g. CCF, 2012a, 2012b), and a public debate leaving traces in media.

Initially, the collection of document data included retrospective events: the start-up of CCF and its background. Reports, internet pages, newspaper articles, newsletters, memos from hearings and workshops, and other material made public by the organisations provided an overview of the initiative, its development, arguments and conflict areas, as well as of key stakeholders. Of particular importance was (i) an open referral during 2008, which resulted in comments from 36 organisations, representing most sectors in society (including government, producers, CSOs and research), (ii) the standards, first presented in 2009, and (iii) background material to each standard area (milk, eggs, packaging, etcetera). Data was also gathered via observation, through participation in a workshop and a conference where ideas and principles were presented and discussed prior to the launch of the standards.

To further examine CCFs development, structure and content, and to assess different actors' interaction and positions relative the initiative, particularly in the formative stage during 2008, 26 semi-structured interviews were performed, recorded and transcribed in verbatim. Respondents were CCF staff, KRAV and SSQ employees, and actors partaking in the stakeholder network forming around the standard development process. Such actors were selected in order to represent organisations "who can affect or is affected by the approach to the issue addressed by the network." (Roloff, 2008, p. 238). As indicated in table 3, the ambition was also to cover different sectors of society, including production, retailing, government agencies, and CSOs.

Table 3. Respondent overview

\begin{tabular}{|c|c|c|c|}
\hline Organisation (acronym) & $\begin{array}{l}\text { Organisation's role in the Swedish food } \\
\text { sector }\end{array}$ & Role of respondent & $\begin{array}{l}\text { No. of interviews } \\
\text { (year) }\end{array}$ \\
\hline $\begin{array}{l}\text { Climate Certification for food } \\
(\mathrm{CCF})\end{array}$ & $\begin{array}{l}\text { Developing a climate standard and labelling } \\
\text { system for food products }\end{array}$ & Project leader & $3(2008)$ \\
\hline a.a. & a.a. & Project leader & $1(2012)$ \\
\hline a.a. & a.a. & Agri-expert & $1(2008)$ \\
\hline KRAV & $\begin{array}{l}\text { Sponsor of main Swedish label for } \\
\text { organics. Initiator of } \mathrm{CCF}\end{array}$ & $\begin{array}{l}\text { Standard development manager/ } \\
\text { CCF steering committee member, }\end{array}$ & $2(2008 / 2010)$ \\
\hline a.a. & a.a. & $\begin{array}{l}\text { Sales manager / CCF chairman } \\
\text { and Quality manager ( } 2 \text { persons) }\end{array}$ & $1(2011)$ \\
\hline Swedish Seal of Quality (SSQ) & $\begin{array}{l}\text { Labeller of Swedish produce, subsidiary to } \\
\text { LRF (see below). Main partner in CCF }\end{array}$ & $\begin{array}{l}\text { Rule developer/ environmental } \\
\text { expert }\end{array}$ & $1(2008)$ \\
\hline a.a. & a.a. & $\begin{array}{l}\text { CEO, CCF steering committee } \\
\text { member }\end{array}$ & $1(2010)$ \\
\hline Lantmännen & $\begin{array}{l}\text { Major farmer-owned Swedish food and } \\
\text { energy group. Multinational operations. }\end{array}$ & $\begin{array}{l}\text { Director of sustainable } \\
\text { development/ CCF steering } \\
\text { committee member, }\end{array}$ & $2(2008 / 2010)$ \\
\hline Scan & Major Northern European meat group & Environmental and & $1(2010)$ \\
\hline
\end{tabular}


manager (Sweden)/ CCF steering

committee member

\begin{tabular}{|c|c|c|c|}
\hline $\begin{array}{l}\text { The Swedish Board of } \\
\text { Agriculture (SBA) }\end{array}$ & $\begin{array}{l}\text { Governmental authority focused on } \\
\text { agri-food policy }\end{array}$ & $\begin{array}{l}\text { Adjunct member of CCF steering } \\
\text { committee }\end{array}$ & $1(2010)$ \\
\hline National Food Administration & $\begin{array}{l}\text { Government agency responsible for food } \\
\text { safety, quality and fair practices }\end{array}$ & Environmental coordinator & $1(2008)$ \\
\hline Svenskdagligvaruhandel (SD) & The Swedish retailer's industry organisation & $\begin{array}{l}\text { CEO and a Product safety and } \\
\text { legislative coordinator ( } 2 \text { persons) }\end{array}$ & $1(2008)$ \\
\hline ICA & $\begin{array}{l}\text { The largest Swedish retailer, belonging to } \\
\text { the Royal Ahold group }\end{array}$ & Environment and CSR manager & $1(2008)$ \\
\hline Arla & Major Northern European dairy company & Environmental manager (Sweden) & $1(2008)$ \\
\hline $\begin{array}{l}\text { The Foundation Biodynamic } \\
\text { Products }\end{array}$ & Niche wholesaler in organics & Chairman & $1(2008)$ \\
\hline $\begin{array}{l}\text { Swedish Society for Nature } \\
\text { Conservation (SSNC) }\end{array}$ & The largest Swedish environmental NGO & Environmental manager & $1(2008)$ \\
\hline Fair trade Sweden & NGO focusing on fair trade & Communication manager & $1(2008)$ \\
\hline Animal Rights Sweden (AR) & Major animal rights NGO & Political director & $1(2008)$ \\
\hline $\begin{array}{l}\text { The Swedish Consumers' } \\
\text { Association (SCA) }\end{array}$ & $\begin{array}{l}\text { The largest Swedish consumer's rights } \\
\text { NGO }\end{array}$ & International secretary & $1(2008)$ \\
\hline $\begin{array}{l}\text { The Swedish Food Federation } \\
\text { (LI) }\end{array}$ & Trade and employers' federation & CEO & $1(2008)$ \\
\hline $\begin{array}{l}\text { Swedish } \quad \text { Environmental } \\
\text { Management Council (SEMCo) }\end{array}$ & $\begin{array}{l}\text { Semi-governmental body in area of } \\
\text { environmentally related procurement and } \\
\text { product information }\end{array}$ & $\begin{array}{l}\text { Manager Environmental Product } \\
\text { Declarations }\end{array}$ & $1(2008)$ \\
\hline $\begin{array}{l}\text { The Federation of Swedish } \\
\text { Farmers (LRF) }\end{array}$ & $\begin{array}{l}\text { Interest and business organisation for } \\
\text { Swedish farmers }\end{array}$ & Environmental manager & $1(2009)$ \\
\hline
\end{tabular}

While the single case study approach allows "a relatively complete rendering of the story within the text" (Eisenhardt \& Graebner, 2007, p. 29), the use of the rich data varies in relation to the components of the assessment (type of source is indicated by capital letters). While structural features are primarily sought for in the standards (S) and through interviews (I), the search for main areas of stakeholder interests and conflicts is made in interview transcripts and referral comments (R), and to a lesser extent through observation (O), background material to the standards and other documents such as press releases from various actors (D). Evidently, the standards are the main source for assessing the content, but other sources play a role in interpreting the implementation and development of the standards and labels. The purpose and variety of sources used renders an aggregate data presentation which follows a longitudinal logic with three phases: start-up, early development, and later development including final outcome.

\section{The Case}

\subsection{Start-Up, Key Actors and Rationale}

The idea for a climate label had been around in the KRAV organisation, but timing was perceived to be right (cf. Reinhardt, 1998) when climate was lifted in the public debate 2006-2007 (I) (e.g. Gore, 2006; IPCC, 2007; Stern, 2006). The project developed when climate change was becoming the environmental problem, and initiatives directed to control or reduce the climate impact of business emerged in Sweden and elsewhere (ID). Early examples include UK retailer Tesco and the Carbon Trust, while major Swedish food sector initiatives that contained labelling or publicly communicated standards are listed in table 4 . 
Table 4. Major climate initiatives in the Swedish food sector (2007-2010)

\begin{tabular}{|c|c|c|}
\hline Backing organization & Type of initiative & Representation in present study \\
\hline KRAV, Swedish Seal of Quality & $\begin{array}{l}\text { Climate standard and labelling system } \\
(\mathrm{CCF})\end{array}$ & Yes, focused, and various sources used \\
\hline KRAV & $\begin{array}{l}\text { Inclusion of climate standards in organic } \\
\text { system }\end{array}$ & $\begin{array}{l}\text { Yes, via organization representative and } \\
\text { documentation }\end{array}$ \\
\hline Lantmännen & LCA based climate declaration & $\begin{array}{l}\text { Yes, via company representative and } \\
\text { documentation }\end{array}$ \\
\hline Max & Climate labelling on fast food & No \\
\hline National Food Administration & Climate advice to consumers & $\begin{array}{l}\text { Yes, via organization representative and } \\
\text { documentation }\end{array}$ \\
\hline $\begin{array}{l}\text { Swedish Environmental Management } \\
\text { Council }\end{array}$ & $\begin{array}{l}\text { Carbon footprint model intended for } \\
\text { inclusion to the EU Ecolabel. }\end{array}$ & $\begin{array}{l}\text { Yes via organization representative and } \\
\text { documentation }\end{array}$ \\
\hline Swedish Seal of Quality & $\mathrm{CCF}$ add-on to regular standard & $\begin{array}{l}\text { Yes, via organization representative and } \\
\text { documentation }\end{array}$ \\
\hline
\end{tabular}

The launch of CCF was related to the idea of steady improvement of the organic standard: It is important for KRAV as a labelling organisation to incorporate environmental dimensions that are salient to consumers. In order to identify relevant dimensions and to ensure a wide acceptance, it is also important to reach many stakeholders (I). When SSQ joined CCF in 2007, the alliance was met with surprise due to competition and conflict between organic and conventional farming, but the organisations were already connected via KRAVs board (ID).

To exchange views, build support and finance the development, other actors were approached, and during autumn 2007, some organizations joined the initiative as active partners (ID): Lantmännen and the Federation of Swedish Farmers (both connected to SSQ), the Swedish Board of Agriculture, and two dairy companies, Milko and Skånemejerier. The commitment was motivated by the urgency of the climate problem and the interest to learn more about climate, standardisation and labelling (I). Nevertheless, the direct role of industry was central, and discussions clearly started out from its activities and interests and not only from scientific facts concerning climate (ID). The government publicly declared its trust in the market actors, its disapproval with compulsory product labelling (including regulation), and recommended existing labelling organisations to run the process (D).

During the first phases of standard development, many other actors including CSOs and research institutions were also involved in different ways. Some of the stakeholder communication was structured through workshops and reference group meetings (ID). As regards the advancement of the process, two potentially conflicting perspectives were inherent in the formal goals. Not only would the sector's climate impact be substantially reduced; CCF would also enhance industry's competitiveness. To accomplish this dual ambition, the overarching means, both formally and dominating in discussions, was to offer and communicate "climate-friendly choices" to consumers (ID). Accordingly, most stakeholders demonstrated a belief in the role and responsibility of consumers (ID), and the development of the standard was instrumental in order to reach a label - the basis for an informed consumer choice. The name of the project remained Climate Labelling for Food for a long time.

\subsection{Early Challenges in Arriving at a Label}

Originally, a standard was scheduled to be delivered to the project owners in June 2008, followed by the launch of a climate label. Prior to this, a wide variety of stakeholders were involved in discussions which culminated in an open referral concerning draft rules (D). The following appeared as key areas for stakeholder interests and conflict and, hence, navigation by the CCF management in developing the system.

Environmental versus commercial interests. Many stakeholders, representing businesses, research and CSOs, expressed an urgent need to counter climate change, and the majority saw CCF as a relevant response to a shared problem. Some (e.g. the Swedish Association of Ecological Farmers) argued that the direction was not strong enough, not following IPCC, while conventional producers saw the risk of an overly strict standard (IR). Others, including the National Board of Trade and ICA, were uneasy about negative effects on trade (IRO). Concern was also raised (by the governmental Swedish Consumer Agency, the CSO SCA, among others) about the possibility to develop a label that consumers can understand, and it was said that a label could cement existing structures and prevent continuous learning and change (IR). 
State of knowledge and what to label. The state of knowledge was used to argue for postponement as well as for a quick launch. Retailing organisations raised concerns about overlooked effects on the established KRAV brand while the draft's treatment of transports gave rise to different types of critique (from, e.g., SSNC, one County Council, the Swedish Environmental Protection Agency and Centre for Sustainable Agriculture) (IR). To some contrast, a SSQ respondent stated that knowledge was quite good, but the question was how much we could handle (I). CCF management pointed out that LCA alone would not be the best approach as updating depending on season, cultivation method, etcetera, would be required (I). Nor could it accommodate all environmental dimensions, why labelling based on production systems, and not products, was chosen (ID).

Should all be able to comply? The draft did not allow grading, but opened the label for all product areas independent of carbon footprint. Two vegetable producers, an ecological food wholesaler and some CSOs argued that this would counteract change of food habits and emphasized that the choice between meat and vegetables is what makes the difference (IR). First, this included KRAV, which presented five advices to those who were "waiting for the label": Finish your meal, eat less meat, vary your meals according to season, don't eat air-freighted foods and choose products certified for environmental and animal protection (KRAV, 2008). Similar advice was developed by the National Food Administration, but withdrawn after anti-protectionism arguments from another governmental body). Others, most notably commercial actors, argued that it was important to guide the consumer to the best products in each category, and the importance of meat producers in the process was recognized by the CCF management (IR). In 2009, advice number 2 and 4 (above) was omitted from the KRAV webpage (KRAV, 2009).

Vertical, horizontal and geographical scope. Although the official ambition was comprehensive, climate impact occurring after delivery to warehouses in the retailing system, and therefore much of the effects of retailer's organisation, and consumer transportation, storing and cooking, was excluded. Regarding the horizontal scope, Kung Markatta criticised the draft for dealing with low-emitting production areas and "symbolic issues" such as transport, while the Swedish Association of Ecological Farmers added that the most important climate factor in crop production, nitrogen supply, was not addressed (R). Others, including retail group Axfood, were positive towards the approach to start with few criteria and product areas (R). CCF management pointed out that rules for many areas, such as packaging and storage, were developed and that areas with strong climate impact, particularly organogenic soils, were targeted, although it could generate socioeconomic problems (I). Geographically, the domestic scope prompted warnings about protectionist outcomes, phrased as advocacy for free trade in general (e.g. the National Board of Trade) or as third world solidarity (e.g. Fair Trade) (IRO).

Should a label be freestanding, add-on, or integrated with existing labels? The critique towards making the label freestanding, or as an add-on to existing labels, was strong. SSNC, SD, National Food Administration and others opposed the suggested separation of climate from other environmental dimensions as it would complicate communication (IRD). Concern was also raised as regards a devaluing effect on the regular KRAV brand (e.g. by ICA and the Swedish Cooperative Union), arguing that KRAV (organics) was the environmental brand which should be updated on climate effects (IR). On the other hand, some organic growers were concerned that their KRAV subscription could be lost if new rules were incorporated into the existing framework (IR).

\subsection{Final Phase: Modification and Operationalization}

Following the referral in 2008, the label was postponed. Some actors were sceptical and others choose to pursue parallel or competing initiatives, including a LCA-based climate declaration (using $\mathrm{CO}_{2} \mathrm{e} / \mathrm{kg}$ ) introduced in April 2008 by CCF sponsor Lantmännen (ID). The general attitude in the industry, however, appeared positive and work continued (ID). The process now involved less instances of open stakeholder interaction, that is, became more hierarchical (cf. Ostrom, 2008), but a significant number of actors continued to be represented in the project organisation: sponsors in the steering group, researchers in the expert panel and various interests in reference groups (D).

In June 2009, CCF presented general criteria along with standards and related background material for farm operations and four activity areas: crops, greenhouses, milk and fisheries (SD). The preamble declared that criteria should substantially reduce the climate impact, but with attention to what was practically and economically feasible.

SSQ decided to have a climate label as add-on to their regular standard while KRAV, stepwise, would integrate the climate standard with existing organic rules (ID). When this became operational, through energy related criteria for fisheries and greenhouse production in the $2010 \mathrm{KRAV}$ standard, it was said to be unique within organic farming (D). As result of these two processes, cod, tomatoes and milk was marketed as certified products 
in May/June 2010 (D). May also saw a new version of the CCF standards, covering four additional areas: beef, pork, egg and transports (S).

The project plan now became more pragmatic, changing the ambition from a significant reduction of emissions in relation to the average farm (25\% was mentioned), to significant reductions of emissions that "could be influenced" (ID). For biological reasons (ruminant digestion), emissions from animals were now largely out of reach, and the project's role in the total change process was moderated (ID).

In early 2012, CCF presented a final standard document containing 15 sets of criteria, including one general section and farm operations. New areas were lamb, chicken, aquaculture, "processing/packaging/handling", and requirements for recognition of equivalent certification systems (to facilitate trade) (SD). The overall content focuses on control and efficiency of processes within primary production, including energy and nitrogen mapping and the use of fertilizer and fodder. In order to reduce emissions per $\mathrm{kg}$ of meat, the standard aims at fast animal growth and maximum length of life, such as 18 months for bulls (independent of breed) and 210 or 160 days for lamb. The latter depends on feeding system, and includes mandatory plans to cut the slaughter age further (SD).

The standard also includes environmentally or systems based criteria, such as restricted use of fossil fuels, synthetic refrigerants, and fodder from soy or other farms. It also bans the reclaiming of organogenic soils through drainage of peatlands (S).

While the SSQ add-on basically meets the CCF standard, KRAV has incorporated a few rules into its system as part of annual revisions (ID). In 2012, when CCF was terminated, 14 companies were certified according to the climate system operated by SSQ while approximately 4,000 producers (mostly within crops) belonged to the KRAV system (D).

Some of the project's impact was indicated in an evaluation commissioned by CCF, claiming reductions in the range of $10-15 \%$ for most of the activity areas, with a high $80 \%$ for greenhouses (through the phasing out of fossil fuels) and a low 3-4\% for beef (Futerra, 2012). This can be related to early project documents, which emphasised cuts within livestock due to its dominant role in agricultural emissions (close to 80\%; KRAV, 2007).

\section{Discussion and Conclusions}

\subsection{Increased Focus, but Less Emphasis on CPR Management}

The case under investigation, $\mathrm{CCF}$, is an attempt to manage the climate commons through voluntary commitment and broad dialogue, largely in line with an approach suggested by Dietz et al. (2003). CCF is also assessed as an attempt to meet specific challenges related to global CPRs (e.g. Ostrom et al., 1999) through the reduction of certain complexities. Initially, this meant focusing on a limited area of human activity (food) in a domestic setting, but the development implied further reduction of complexity. Here, the rationale was mainly other than CPR management. Influences came through stakeholder interaction, and the process led to change in stakeholder involvement. The project came to focus primary production, became more hierarchical, abandoned the label and consumer focus, and turned its attention towards an economically sound adjustment of current activities.

The vertical focus was explained by scientific facts, stating that primary production hold the main emission sources. It is also related to what actors CCF attracted and to the feasibility to cover and communicate climate impact within the food sector. This also came to neutralize the scientific arguments first used, as the main animal related - emissions were declared to be unmanageable. For similar reasons, CCF largely excluded emissions occurring through processing, retail and consumption.

The decrease of open communication with stakeholders, which initially included basically any domestic actor with a stake in the food sector, to keep development between assigned parties (project team, steering group, expert and reference groups), can be explained by consolidation within the group of sponsors but also as a matter of balancing conflict solution with conflict avoidance. Moving from a process characterized by influence from a stakeholder network, in which problems with achieving action is recognized (Warner, 2006), towards a project network, and an organisation with fewer members with sufficient commonalities, is in line with literature on temporary organizations (Lundin \& Söderholm, 1995).

Leaving the label and consumer outside the process was a substantial deviation from the project's starting points, which defined the consumer as the responsible and willing change agent and the aim to enable change through the provision of information to this agent. The exclusion of the key actor and instrument means that new explanations and mechanisms are needed for CCF as a governance system. This leads to the fourth aspect of complexity reduction that appeared during the process, as change largely became identified with efficiency 
increasing measures. Such criteria are well aligned with current strategies and operations of producing firms, the stakeholder category that became salient for CCF management (Mitchell et al., 1997).

\subsection{Structural Advantages and Weaknesses}

Turning to the initiative's structure, an attempt to position CCF is made in table 5. As with practically any governance system dealing with global CPRs, a fundamental weakness is the absence of the majority of affected parties (including future resource users; cf. Gardiner 2011) in dialogue (3) and conflict resolution (6). Most design principles (Ostrom, 2005) are met to some degree, but the voluntary form and far-reaching reduction of complexity pose limitations. Although boundaries are relatively clear (1), most users within the defined category are not participating, implying that Hardin's (1968) criteria for mutually agreed coercion is not met. Further, as appropriators can not defend the resource from outsiders (cf. Morrow \& Hull, 1996; Ostrom, 2005), such actors can continue to benefit from high-harvesting strategies without costs from this system. CCF also (2) focuses on a reduction of emissions relative to output rather than CPR management, and sanctions (5) are only operational as long as users of the standard find balancing benefits, mainly addressed as brand value or efficiency gains.

Table 5. Case findings in relation to Ostrom's (2005) design principles

\begin{tabular}{lll}
\hline Design principle & Consistent findings & Inconsistent findings \\
\hline (1) Well-defined boundaries & $\begin{array}{l}\text { Addresses parts of the food sector in Sweden } \\
\text { (primary production mainly), and its share of the } \\
\text { human use of the climate common. }\end{array}$ & $\begin{array}{l}\text { Voluntary for producers (and consumers, to } \\
\text { the extent they are informed). }\end{array}$ \\
\hline (2) Proportional equivalence & Fairness backed by adaptation to established & Harvesting primarily targeted in relative terms \\
between benefits and costs & $\begin{array}{l}\text { certification systems. Rules congruent with local } \\
\text { conditions. }\end{array}$ & $\begin{array}{l}\text { organogenic soil and fossil fuel restrictions). } \\
\text { Benefits exploitable in economic terms (e.g. } \\
\text { efficiency gains and brand value). }\end{array}$ \\
\hline
\end{tabular}

(3) Collective-choice High openness to participation by domestic Process led to exclusion of consumers and to

arrangements stakeholders in rule making. Evolving system well adapted to local circumstances. less open stakeholder interaction. User involvement in future development and operation uncertain.

\begin{tabular}{|c|c|c|}
\hline (4) Monitoring & $\begin{array}{l}\text { Third party certification (well established form of } \\
\text { monitoring). }\end{array}$ & $\begin{array}{l}\text { Certification bodies are not appropriators or } \\
\text { directly accountable to appropriators. }\end{array}$ \\
\hline (5) Graduated sanctions & $\begin{array}{l}\text { Rule infractions are treated (gradually) within the } \\
\text { system which operate CCF criteria (KRAV and } \\
\text { SSQ). }\end{array}$ & $\begin{array}{l}\text { As the system is voluntary, sanctions relate to } \\
\text { use of standard and label, not of resource. }\end{array}$ \\
\hline Conflict-resolution & $\begin{array}{l}\text { Emphasised as open process in the first phases and } \\
\text { through sponsor dialogue and expert counselling } \\
\text { later on. Finally available through operating } \\
\text { organisations' rule setting processes. }\end{array}$ & $\begin{array}{l}\text { As the system is voluntary, major disputes } \\
\text { mean non-participation, individual } \\
\text { exit/exclusion or failure of the whole system. }\end{array}$ \\
\hline $\begin{array}{l}\text { (7) Minimal recognition of rights } \\
\text { to organize }\end{array}$ & $\begin{array}{l}\text { Yes, and initiative actively supported by } \\
\text { Government. }\end{array}$ & n.a. \\
\hline (8) Nested enterprises & $\begin{array}{l}\text { Standards open for other operators, related to } \\
\text { processes within individual organisations, and } \\
\text { non-conflicting with governmental measures and } \\
\text { international agreements. }\end{array}$ & $\begin{array}{l}\text { Nesting primarily potential or indirect; no } \\
\text { sufficient polycentric system exists. }\end{array}$ \\
\hline
\end{tabular}

Regarding the five requirements of adaptive governance (Ostrom, 2008; Dietz et al., 2003), information was central in the CCF process and appear to, largely, "meet high scientific standards and serve ongoing needs of decision makers and users" (Dietz et al., 2003, p. 1908). The limitation is due to the project's narrow definition of users. Further, while participating actors benefited from new knowledge, attentiveness to aggregate conditions diminished as the focus turned increasingly towards production and producer interests. In a similar vein, the first phase's openness and variety in forms of interaction enabled the detection of conflict areas, and most likely learning (de Boer, 2003; Dietz et al., 2003). The ensuing narrowing and result-orientation of the project, however, 
meant priorities other than CPR management, with the inclusion of moderately improved meat production in the system as the overt example.

The possibility to induce rule compliance is obviously limited as the system is voluntary. It is also adopted by few resource users and did not reach its purpose of creating a label for consumers. On the other hand, the open rule-setting process, its scientific base, well established key actors, and third party certification, creates a basis for the system to be perceived as fair and legitimate. The use within KRAV implies that criteria are incorporated into a functioning system that makes brand users accountable, while the SSQ add on allows early adopters to benefit from the use if the label becomes successful on the market (cf. Dietz et al., 2003, p. 1909).

At least during its development, CCF provided technological and institutional infrastructure. It initiated and disseminated research on agricultural practices and climate change, which may influence the technologies by which the commons is exploited (cf. Dietz et al., 2003). CCF also provided a platform for interaction on these issues, involving government, industry and CSOs, possibly enhancing knowledge as well as social capital (Driscoll, 1996; Warner, 2006), and, still in the national setting, its design suits other levels of governance (through, e.g., the links to existing standards, support from Government and focus on broadly accepted market oriented measures). Its intention for international use, however, "as an add-on to a system that certifies basic sustainability performance" (CCF, 2012a, p. 57), may be hampered as this poses requirements within other issues, including pesticides, GMO, biodiversity, social rights and animal husbandry. Systems meeting such aims may well have other ambitions regarding climate or find contradictions between the largely industrial perspective of CCF and change towards a sustainable food system. Not least may the focus on production efficiency for animals counteract ambitions for good animal husbandry and biodiversity (including the variety of animals kept in production systems). On the other hand, the relatively strong environmental profile of Swedish agricultural policy, and the pioneering traits of $\mathrm{CCF}$, may aid international learning from the case.

The fifth requirement of adaptive governance, preparedness for change, is eased by the choice of production system based standards, avoiding exact measures on product labels. The need for continuous development was also recognized and prepared for, as the standard document include recommendations beyond mandatory improvements. The uncertainties regarding future operations of the system, however, make it unclear how it will "address past errors and cope with new developments" (Ostrom, 2008, p. 18).

\subsection{The Project's Achievements and Limitations}

The area of change leads to final remarks about the system's potential in terms of prudent management of the climate commons. On the positive side, the case produced arguments for why an initiative such as the CCF, in which much of the complexity associated with CPR governance is reduced, could be successful. First, given its demarcation to a domestic sector, the process had broad stakeholder involvement and contributed to learning and promoted the climate issue outside the project itself (e.g. stimulated organisational level measures or policy; cf. Rubik, Frankl, Pietroni, \& Scheer, 2007). Second, largely based on the shared understanding of the problem, grounded in scientific explanations, standards were ultimately produced. These standards call for change beyond legislative requirements, even though large mainstream actors dominated the process.

The latter, however, posed constraints for the outcome (cf. Bloomfield, 2012). Whereas some environmental criteria were indeed incorporated into market activities through the standard, the bulk of criteria were made to increase industrial and economic efficiency, thus aiming for relative and not absolute gains in the quest for prudent CPR management. The outcome is not only far from the need for change. It is also far from the initiators' early ambitions: The main area of emission sources (animals) and the main change mechanism (consumer choice) were both devalued, and the dual goals of climate mitigation and industrial competitiveness became unbalanced in favour of the latter as complexity was reduced further.

The circumstances may not yet have been fertile enough for the more progressive ideas. In such a light, neither market pressures, nor political and regulatory systems, were sufficient to enable the full success of the initiative (cf. Alberini \& Segerson, 2002; Gulbrandsen, 2005). This underlines the importance of change at many levels, in different types of governance (Anh et al., 2011; Hovik et al., 2010; Ostrom, 2005; Paavola, 2008; Stern, 2011). Hence, a government should not only present its trust in market actors, but take policy measures that prove commitment to mitigation in line with the less negative IPCC scenarios and support more radical steps by voluntary initiatives.

Here, one can instead refer to a central theme in Hardin's article, the "implicit and almost universal assumption" (Hardin, 1968: 1243) that problems are seen to have technical solutions, in contrast to posing new demands on human values or ideas of morality (cf. Gardiner, 2011; Mitchell, 2012; Oels, 2005). The CCF process could even have locked us further into a non-sustainable industrial view of the human-nature relation, emphasizing 
productivity and the role of ecosystems and other species in human production systems. CCF did not fundamentally challenge the role of independent, rational, free-enterprisers (Hardin, 1968; cf. Bloomfield, 2012) or of the role and distribution of property. Hence, the initiative could simultaneously have promoted relatively minor emission reductions and prevented large-scale change. Another interpretation is that the process was a catalyst for (later) change as it lifted climate and responsibility on mainstream corporate agendas.

Learning from this case may be influenced and restricted by the sector's high share of total emissions, its embeddedness in agricultural policy and food regulation, Sweden's relatively progressive environmental ambitions among high-emitting nations, and the fact that CCF was among the early initiatives of its kind. Nevertheless, it shows that voluntary complexity-reducing initiatives may promote awareness and ambitions regarding climate, but that it is also difficult to deviate from prevailing unsustainable perspectives and priorities. In order to balance local interests and power with global and intertemporal values, which includes reaching absolute emission cuts, change in societal norms (Hay, 2005; Lamberton, 2005) as well as support from other institutional layers (e.g. government policy and international agreements) would be needed.

\section{References}

Anh, P. T., Bush, S. R., Mol, A. P. J., \& Kroeze, C. (2011). The Multi-Level Environmental Governance of Vietnamese Aquaculture: Global Certification, National Standards, Local Cooperatives. Journal of Environmental Policy \& Planning, 13(4), 373-397. http://dx.doi.org/10.1080/1523908X.2011.633701

Alberini, A., \& Segerson, K. (2002). Assessing Voluntary Programs to Improve Environmental Quality. Environmental and Resource Economics, 22(1-2), 157-184. http://dx.doi.org/10.1023/A:1015519116167

Armour, L. (1997). The logic of Economic Discourse: beyond Adam Smith and Karl Marx. International Journal of Social Economics, 24(10), 1056-1079. http://dx.doi.org/10.1108/03068299710184877

Beland Lindahl, K., Baker, S., \& Waldenström, C. (2013). Place Perceptions and Controversies over Forest Management: Exploring a Swedish Example. Journal of Environmental Policy \& Planning, 15(2), 201-223. http://dx.doi.org/10.1080/1523908X.2012.753316

Bloomfield, M. J. (2012). Is Forest Certification a Hegemonic Force? The FSC and its Challengers. The Journal of Environment \& Development, 21(4), 391-413. http://dx.doi.org/10.1177/1070496512449822

Bonnedahl, K. J., \& Eriksson, J. (2011). The role of discourse in the quest for low-carbon economic practices: A case of standard development in the food sector. European Management Journal, 29(3), 165-180. http://dx.doi.org/10.1016/j.emj.2010.10.008

Brown, L. R. (2011). World on the Edge: How to Prevent Environmental and Economic Collapse. Earth policy institute. New York: W.W. Norton \& Company.

Bunzl, M. (2009). Climate and the Commons-a Reappraisal. Climatic Change, 97(1-2), 59-65. http://dx.doi.org/10.1007/s10584-009-9697-9

Burger, J., \& Gochfeld, M. (1998). The Tragedy of the Commons. 30 Years Later. Environment, 40(10), 4-27. http://dx.doi.org/10.1080/00139159809605104

CCF (Climate certification for food) (2012a). Klimatcertifieringför mat 2012:2 [Climate certification for food: Final standard document]. Retrieved May 17, 2012, from http://www.klimatmarkningen.se/regelverket/alla-regler

CCF (Climate certification for food) (2012b). Underlagsrapporter [Background reports to standards]. Retrieved April 30, 2012, from http://www.klimatmarkningen.se/underlagsrapporter

Crutzen, P. J. (2002). Geology of Mankind: the Anthropocene. Nature, 415, 23. http://dx.doi.org/10.1038/415023a

De Boer, J. (2003). Sustainability Labelling Schemes: The Logic of their Claims and their Functions for Stakeholders. Business Strategy and the Environment, 12(4), 254-264. http://dx.doi.org/10.1002/bse.362

Dietz, T., Ostrom, E., \& Stern, P. C. (2003). The Struggle to Govern the Commons. Science, 302, 1907-1912. http://dx.doi.org/10.1126/science.1091015

Driscoll, C. (1996). Fostering Constructive Conflict Management in a Multi stakeholder Context: The Case of the Forest Round Table on Sustainable Development. The International Journal of Conflict Management, 7(2), 156-172. http://dx.doi.org/10.1108/eb022780 
Duit, A., Galaz, V., Eckerberg, K., \& Ebbesson, J. (2010). Governance, Complexity, and Resilience. Global Environmental Change, 20(3), 363-368. http://dx.doi.org/10.1016/j.gloenvcha.2010.04.006

Eisenhardt, K. M., \& Graebner, M. E. (2007). Theory building from cases: Opportunities and Challenges. Academy of Management Journal, 50(1), 25-32. http://dx.doi.org/10.5465/AMJ.2007.24160888

Erlich, P. R., \& Holdren, J. P. (1971). Impact of Population Growth. Complacency Concerning this Component of Man's Predicament is Unjustified and Counterproductive. Science, 171, 1212-1217. http://dx.doi.org/10.1126/science.171.3977.1212

FAO (Food and Agriculture Organization of the United Nations). (2006). Livestock's Long Shadow. Environmental Issues and Options. Rome: FAO.

Feindt, P. H. (2010). Policy-learning and Environmental Policy Integration in the Common Agricultural Policy, 1973-2003. Public Administration, 88(2), 296-314. http://dx.doi.org/10.1111/j.1467-9299.2010.01833.x

Frooman, J. (2010). The Issue Network: Reshaping the Stakeholder Model. Canadian Journal of Administrative Sciences, 27(2), 161-173. http://dx.doi.org/10.1002/cjas.150

Frye-Levine, L. A. (2012). Sustainability through Design Science: Re-Imagining Option Spaces Beyond Eco-Efficiency. Sustainable Development, 20(3), 166-179. http://dx.doi.org/10.1002/sd.1533

FSC (Forest Stewardship Council) (1996). FSC International Standard: FSC Principles and Criteria for Forest Stewardship. FSC-STD-01-001 (version 4-0). EN. Bonn: FSC.

Futerra. (2012). Projekt klimatutvärdering, Slutredovisning [Project climateevaluation, final] April 142012. Stockholm: Futerra Sustainability Communications.

Gardiner, S. M. (2002). The Real Tragedy of the Commons. Philosophy \& Public Affairs, 30(4), 387-416. http://dx.doi.org/10.1353/pap.2002.0003

Gardiner, S. M. (2011). A Perfect Moral Storm: The Ethical Tragedy of Climate Change. New York: Oxford University Press.

Gore, A. (2006). An Inconvenient Truth: The Planetary Emergency of Global Warming and What We Can Do About It. New York: Rodale.

Gulbrandsen, L. H. (2005). Sustainable Forestry in Sweden: The Effect of Competition Among Private Certification Schemes. The Journal of Environment \& Development, 14(3), 338-355. http://dx.doi.org/10.1177/1070496505280061

Halinen, A., \& Törnroos, J. Å. (2005). Using Case Methods in the Study of Contemporary Business Networks. Journal of Business Research, 58, 1285-1297. http://dx.doi.org/10.1016/j.jbusres.2004.02.001

Hardin, G. (1968). The Tragedy of the Commons. Science, 162, 1243-1248. http://dx.doi.org/10.1126/science.162.3859.1243

Hardin, G. (1998). Extensions of "The Tragedy of the Commons". Science, 280(5364), 682-683. http://dx.doi.org/10.1126/science.280.5364.682

Hay, R. (2005). Becoming Ecosynchronous, part 1. The Root Causes of Our Unsustainable Way of Life. Sustainable Development, 13, 311-325. http://dx.doi.org/10.1002/sd.256

Hovik, S., Sandström, C., \& Zachrisson, A. (2010). Management of Protected Areas in Norway and Sweden: Challenges in Combining Central Governance and Local Participation. Journal of Environmental Policy \& Planning, 12(2), 159-177. http://dx.doi.org/10.1080/15239081003719219

Hsu, S. L. (2006). What IS a Tragedy of the Commons? Overfishing and the Campaign Spending Problem. Albany Law Review, 69(1), 75-138. http://dx.doi.org/10.2139/ssrn.668723

IPCC (The Intergovernmental Panel on Climate Change). (2007). Summary for Policymakers. In Solomon, S., Qin, D., Manning, M., Chen, Z., Marquis, M., Averyt, K. B., Tignor, M., \& Miller, H. L. (Eds.), Climate Change 2007: The Physical Science Basis. Contribution of Working Group I to the Fourth Assessment Report of the Intergovernmental Panel on Climate Change. Cambridge: Cambridge University Press.

Jordan, A., Wurzel, R. K. W., \& Zito, A. R. (2013). Still the century of 'new' environmental policy instruments? Exploring patterns of innovation and continuity. Environmental Politics, 22(1), 155-173. http://dx.doi.org/10.1080/09644016.2013.755839 
Kolk, A., \& Pinkse, J. (2004). Market Strategies for Climate Change.European Management Journal, 22(3), 304-314. http://dx.doi.org/10.1016/j.emj.2004.04.011

KRAV. (2007). Mat \& Klimat - bakgrund inför KRAVs klimatseminarium 26 april 2007. [Food \& Climate background to the KRAV climate seminar, April 26 2007]. Uppsala: KRAV.

KRAV. (2008). Klimatprojektet: Vad kan man göra i väntan på märket? [The Climate project: What can you do waiting for the label?]. Retrieved August 6, 2008 from www.krav/klimat/klimatprojektet

KRAV. (2009). Tre enkla tips för att äta klimatsmart. Temablad: Klimat 2009-10-03 [Three simple advice for climate-clever eating. Theme climate October 3, 2009].Retreived December 6, 2012, from http://www.krav.se/Om-KRAV/Fran-temabladet/Fyra-enkla-tips-for-att-ata-klimatsmart/

Lamberton, G. (2005). Sustainable Sufficiency - an Internally Consistent Version of Sustainability. Sustainable Development, 13, 53-68. http://dx.doi.org/10.1002/sd.245

Lundin, R. A., \& Söderholm, A. (1995). A Theory of the Temporary Organization. Scandinavian Journal of Management, 11(4), 437-455. http://dx.doi.org/10.1016/0956-5221(95)00036-U

MA (Millennium Ecosystem Assessment). (2005). Ecosystems and Human Well-being: Synthesis. Washington DC: Island Press.

McKibben, B. (1989). The end of nature. New York: Random House.

Mitchell, R. B. (2012). Technology Is Not Enough: Climate Change, Population, Affluence, and Consumption. Journal of Environment \& Development, 21(1), 24-27. http://dx.doi.org/10.1177/1070496511435670

Mitchell, R. K., Agle, B. R., \& Wood, D. J. (1997). Toward a Theory of Stakeholder Identification and Salience: Defining the Principle of Who and What really counts. Academy of Management Review, 22(4), 853-886. http://dx.doi.org/10.5465/AMR.1997.9711022105

Morrow, C. E., \& Hull, R. W. (1996). Donor-Initiated Common Pool Resource Institutions: The Case of the Yanesha Forestry Cooperative. World Development, 24(10), 164-1657. http://dx.doi.org/10.1016/0305-750X(96)00064-2

NOAA (National Oceanic and Atmospheric Administration). (2013). Trends in Atmospheric Carbon Dioxide, Recent Mauna Loa $\mathrm{CO}_{2}$. Retrieved April 24, 2013, from http://www.esrl.noaa.gov/gmd/ccgg/trends/

Okereke, C. (2007). An Exploration of Motivation, Drivers and Barriers to Carbon Management: The UK FTSE 100. European Management Journal, 25(6), 475-486. http://dx.doi.org/10.1016/j.emj.2007.08.002

Oels, A. (2005). Rendering climate change governable: From biopower to advanced liberal government? Journal of Environmental Policy \& Planning, 7(3), 185-207. http://dx.doi.org/10.1080/15239080500339661

Ostrom, E. (1990). Governing the Commons: The Evolution of Institutions for Collective Action. New York: Cambridge University Press.

Ostrom, E., Burger, J., Field, C. B., Norgaard, R. B., \& Policansky, D. (1999). Revisiting the Commons: Local Lessons, Global Challenges. Science, 284, 278-282. http://dx.doi.org/10.1126/science.284.5412.278

Ostrom, E. (2000). The Danger of Self-Evident Truths. PS: Political Science and Politics, 33(1), 33-44. http://dx.doi.org/10.2307/420774

Ostrom, E. (2005). Understanding Institutional Diversity. Princeton: Princeton University Press.

Ostrom, E. (2008). The Challenge of Common-Pool Resources. Environment, 50(4), 8-20. http://dx.doi.org/10.3200/ENVT.50.4.8-21

Paavola, J. (2008). Governing Atmospheric Sinks: the Architecture of Entitlements in the Global Commons. International Journal of the Commons, 2(2), 313-336.

PBL \& IES (Netherlands Environmental Assessment Agency and Institute for Environment and Sustainability of the European Commission's Joint Research Centre). (2011). Long-term trend in global CO2 emissions. 2011 report. Haag: PBL Netherlands Environmental Assessment Agency.

Pettigrew, A. M. (1990). Longitudinal Field Research on Change: Theory and Practice. Organization Science, 1(3), 267-292. http://dx.doi.org/10.1287/orsc.1.3.267

Reinhardt, F. L. (1998). Environmental Product Differentiation: Implications for Corporate Strategy. California Management Review, 40(4), 43-73. 
Rockström, J., Steffen, W., Noone, K., Persson, Å., Chapin III, F. S., Lambin, E. F., ... Foley, J. A. (2009). Planetary Boundaries: Exploring the Safe Operating Space for Humanity. Ecology and Society, 14(2), 32

Roloff, J. (2008). Learning from Multi-Stakeholder Networks: Issue-Focussed Stakeholder Management. Journal of Business Ethics, 82(1), 233-250. http://dx.doi.org/10.1007/s10551-007-9573-3

Rubik, F., Frankl, P., Pietroni, L., \& Scheer, D. (2007). Eco-labelling and Consumers: Towards a Re-focus and Integrated Approaches. Int. J. Innovation and Sustainable Development, 2(2), 175-191. http://dx.doi.org/10.1504/IJISD.2007.016932

Sachs, J. D. (2011). Beyond the Tipping Point: Global Governance in the Era of Environmental Upheaval. Speech held May $10^{\text {th }} 2011$ at the 17th Annual International Sustainable Development Research Conference, Columbia University, New York, USA.

Siggelkow, N. (2007). Persuasion with Case Studies. Academy of Management Journal, 50(1), 20-24. http://dx.doi.org/10.5465/AMJ.2007.24160882

Sonesson, U., Davis, J., \& Ziegler, F. (2010). Food Production and Emissions of Greenhouse Gases. An overview of the climate impact of different product groups. SIK-Report No. 802. Göteborg: The Swedish Institute for Food and Biotechnology.

Soroos, M. S. (1998). Preserving the Atmosphere as a Global Commons.Environment, 40(2), 7-35. http://dx.doi.org/10.1080/00139159809605089

Steffen, W., Grinewald, J., Crutzen, P., \& McNeill, J. (2011). The Anthropocene: Conceptual and Historical Perspectives. Philosophical Transactions of The Royal Society, 369, 842-867. http://dx.doi.org/10.1098/rsta.2010.0327

Stern, N. (2006). The Economics of Climate Change. The Stern Review.HM Treasury. Retrieved June 7, 2010 from http://www.hm-treasury.gov.uk/independent_reviews/stern_review_economics_climate_change/

Stern, P. C. (2011). Design Principles for Global Commons: Natural Resources and Emerging Technologies. International Journal of the Commons, 5(2), 213-232.

Trucost. (2013). Natural Capital as Risk: The Top 100 Externalities of Business. London, UK: Trucost Plc.

UNEP (United Nations Environment Programme). (2011). Bridging the Emissions Gap. Nairobi: UNEP.

Warner, J. F. (2006). More Sustainable Participation? Multi-Stakeholder Platforms for Integrated Catchment Management, International Journal of Water Resources Development, 22(1), 15-35. http://dx.doi.org/10.1080/07900620500404992

The World Bank. (2012). Turn Down the Heat: Why a $4^{\circ}$ Warmer World Must be Avoided. A Report for the World Bank by the Potsdam Institute for Climate Impact Research and Climate Analytics. Washington: International Bank for Reconstruction and Development / The World Bank.

\section{Copyrights}

Copyright for this article is retained by the author(s), with first publication rights granted to the journal.

This is an open-access article distributed under the terms and conditions of the Creative Commons Attribution license (http://creativecommons.org/licenses/by/3.0/). 